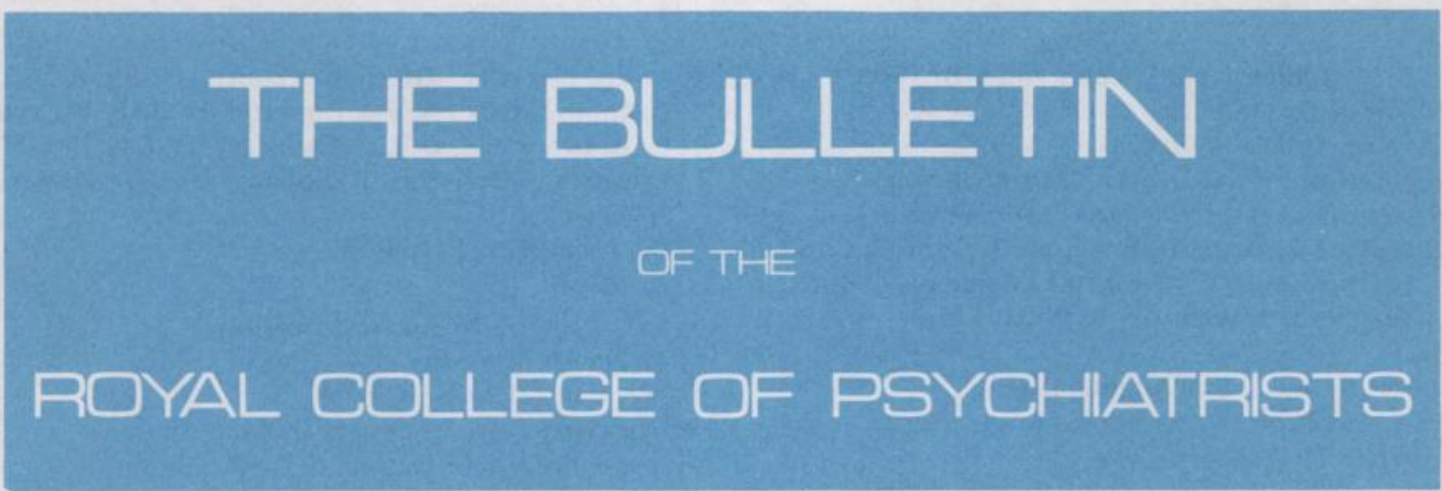

\title{
COLLEGE NEWS \\ ELECTION OF HONORARY OFFICERS \\ ELECTIONS TO FILL VACANCIES ON THE COURT OF ELECTORS AND FOR ELECTED MEMBERS OF COUNCIL
}

Fellows and Members of the College are reminded of their rights in connection with the forthcoming elections for the offices of Dean, Registrar, Treasurer, Editor, Librarian, and Sub-Deans. The relevant sections of the Bye-Laws and Regulations are printed on page 52 of this issue.

In accordance with Bye-Law XV Dr Wilfrid Warren, having held office as Treasurer for seven years, is not eligible for re-election, Dr C. P. Brook has served for five years as Sub-Dean and is not eligible for reelection. (Bye-Law XVIII). The other Honorary Officers are eligible.
The nominating meeting of Council will be held on 14 March 1979, and the last date for receiving nominations will therefore be 12 April 1979.

Fellows and Members are also reminded that nominations may be submitted for vacancies on the Court of Electors and for Elected Members of Council. The relevant Bye-Law and Regulation will be found on page 52 of this issue. Lists of Officers and members of Council and the Court of Electors were published in the Bulletin for January 1979.

\section{Contents}

College News :

Election of Honorary Officers: Elections to fill Vacancies on the Court of Electors and for Elected Members of Council

Officers of Divisions, Sections and Groups

Parliamentary News (to Christmas Recess, 1978)

Spring Quarterly Meeting concessionary travel: a correction

The College's Comments on the Report of the Royal Commission on Gambling: Summary

Psychotherapy Section

Workshop in Research Methods for Psychiatry
Regional Secure Units:

1. Rainford Ward, Rainhill Hospital,

Merseyside; by Dr J. Higgins

2. The Lyndhurst Unit at Knowle Hospital,

Fareham, Hants; by Dr M. Faulk

The Use and Misuse of Confidential Information; by Dr Zaida M. Hall

Safeguarding Confidentiality: a reply;

by Professor J. K. Wing

Correspondence

Forthcoming Events

51

The views expressed in articles published in the Bulletin (except official College material) are the aughors' own and do not necessarily represent College Policy. 


\section{ELECTION OF OFFICERS, COUNCIL AND COURT OF ELECTORS}

\section{BYE-LAWS}

Section XII THE OTHER HONORARY OFFICERS

1. The Council shall, in accordance with the Regulations, make its nominations for the offices of Dean, Registrar, Treasurer, Editor, Librarian and Sub-Deans at the first meeting after the name of the President for the next ensuing College year has become known. Written nominations for the above Honorary Officers, accompanied in each case by the nominee's written consent to stand for election, may also be lodged with the Registrar at such time as may be prescribed by the Regulations, provided that each such nomination is supported in writing by not less than twelve Members of the College who are not members of the Council.

2. The Dean, Registrar, Treasurer, Editor and Librarian shall be elected from amongst the Fellows, and the Sub-Deans shall be elected from amongst the Members of the College, by the Members of the College, in each case in accordance with the procedure prescribed by the Regulations.

\section{REGULATIONS}

XII ELECTION OF THE OTHER HONORARY OFFICERS

1. The method of electing the Honorary Officers other than the President and the Vice-Presidents shall be the same as that for electing the President*, save that nominations from Members of the College who are not members of the Council shall be lodged with the Registrar between the first day of January in any calendar year and the date which is four clear weeks after that meeting of the Council which is first held after the name of the President for the next ensuing College year has become known, or (as the case may be) which is four clear weeks after that meeting of the Council which, in the case of a tie on the second ballot, determines the election of the President.

\section{THE TREASURER}

7. The Treasurer shall not hold office as such for a term of more than seven consecutive College years.

\section{THE SUB-DEANS}

2. No Sub-Dean shall hold office as such for a term of more than five consecutive College years.

\section{BYE-LAWS}

Section XXI THE COURT OF ELECTORS

5. At the first meeting of the Council after the name of the President for the next ensuing College year has become known, the Council shall nominate a sufficient number of candidates for appointment as Electors to ensure an election, which will be held by a postal ballot of all Members of the College in the manner prescribed by the Regulations. Additional nominations may be lodged with the Registrar between the beginning of the then current calendar year and the end of four clear weeks after the meeting of the Council above referred to. No such nomination shall be valid unless it be supported in writing by twelve Members of the College and accompanied by the nominee's written consent to serve if elected.

\section{REGULATIONS}

XIX THE COUNCIL

3. The Council shall, at its first meeting in each College year after the name of the President for the next ensuing College year has become known, nominate for election to the Council twelve or more Members of the College. Any nominee who is proposed and seconded and gives his consent in writing to serve shall be validly nominated. Any twelve Members of the College may make nominations in writing at any time between the first day of January in each year and the date which is four clear weeks after the meeting of the Council at which its nominations are made. Nominations other than those made by the Council shall be lodged with the Registrar and accompanied by the written consent of the candidate to serve if elected. Should there be more nominations than vacancies, an election shall be held by ballot of the Members of the College. The ballot paper shall not indicate the methods of nomination or the names of those nominating. If the number of nominees does not exceed the number of vacancies, these nominees shall be declared elected at the first meeting, whether of the Council or of the Executive and Finance Committee, after the expiry of the period of four clear weeks in this paragraph referred to.

\footnotetext{
* i.e. Written noninations, accompanied in each case by the nominee's written consent to stand for election, may be lodged with the Registrar, provided that each such nomination is supported in writing by not less than twelve Members of the College who are not members of the Council., An election by ballot shall be held in accordance with the provisions of the Regulations.
} 